\title{
Analisis Sentimen Physical Distancing pada Twitter Menggunakan Text Mining dengan Algoritma Naive Bayes Classifier
}

\author{
${ }^{1}$ Nila Hardi, ${ }^{2}$ Yuris Alkahfi, ${ }^{3}$ Popon Handayani, ${ }^{4}$ Windu Gata, ${ }^{5}$ Muhammad Rifqi Firdaus* \\ 1,2,4,5 Program Studi Magister Ilmu Komputer, STMIK Nusa Mandiri \\ ${ }^{3}$ Program Studi Sistem Informasi, STMIK Nusa Mandiri \\ Jl. Kramat Raya No.18, RT.5/RW.7, Kwitang, Kec. Senen, Kota Jakarta Pusat, Daerah Khusus \\ Ibukota Jakarta 10450 \\ *e-mail: 14002358@nusamandiri.ac.id
}

(received: 11 November 2020, revised: 21 November 2020, accepted: 6 Desember 2020)

\begin{abstract}
Abstrak
Physical distancing kini sedang ramai menjadi perbincangan publik sebagai salah satu cara pemerintah dalam menekan penyebaran virus covid-19 yang sedang melanda beberapa negara di belahan dunia. Tidak tersaringnya cuitan terkait physical distancing bisa memunculkan berbagai macam opini, tidak hanya opini yang positif tapi juga yang negatif. Maka dari itu, Twitter di anggap lebih diminati oleh masyarakat indonesia dikarenakan twitter dirasa lebih mudah untuk mengungkapkan opininya. Metode yang digunakan yaitu Naive Bayes Classifier (NBC). Data terkumpul dilakukan filter dari cuitan tersebut dengan menghapus data yang double maka setelah di filter data yang terambil yaitu sebanyak 547 tweets. Pada perhitungan analisis sentimen terhadap physical distancing di tengah pandemi covid-19 menggunakan metode NBC memperoleh hasil akurasi sebesar 50,26\%. Tujuan dari penelitian ini, agar dapat mengkategorikan opini negatif atau positif, dari pembahasan physical distancing. Nantinya informasi terkait kebijakan Physical Distancing bisa sampai tepat informasinnya kepada masayarakat.
\end{abstract}

Kata Kunci: nä̈ve bayes, physyical distancing, twitter

\begin{abstract}
Physical distancing is now busy becoming a public conversation as a way for the government to spread the Covid-19 virus which is currently hitting several countries around the world. There are public tweets related to physical distance that is free from various kinds of opinions, not only positive but also negative ones. Therefore, Indonesian people consider Twitter to be more desirable because it is easier for Indonesians to express their opinion. The method used is the Naive Bayes Classifier $(N B C)$. The data collected was filtered from the tweets with double data, then after filtering the data were taken as many as 547 tweets. In calculating the sentiment analysis of physical distance in the middle of the Covid-19 pandemic using the NBC method, it gets an accurate result of $50.26 \%$. The purpose of this study, to find and categorize negative or positive opinions, from the discussion of physical distancing. So that the implementation of the Physical Distance policy can get accurate information to the public.
\end{abstract}

Keywords: naïve bayes, physical distancing, twitter

\section{Pendahuluan}

Sebagai media komunikasi masyarakat, jejaring sosial semakin popular digunakan. Salah satu jejaring sosial yang cukup popular yaitu twitter. Twitter dapat dimanfaatkan sebagai sarana promosi produk, iklan, kampanye politik maupun sebagai sarana menyampaikan pendapat terkait kritik, saran, isu-isu dan opini-opini publik[1]. Angka penyebaran COVID-19 yang begitu besar membuat beberapa masyarakat menjadi sedikit parno. Pemerintah pun mengeluarkan kebijakan Physical Distancing [2][3].Physical distancing kini sedang ramai menjadi perbincangan publik sebagai salah satu cara pemerintah dalam menekan penyebaran virus covid-19 yang sedang melanda beberapa 
Negara di belahan dunia. Terdapat cuitan-cuitan masyarakat yang terkait physical distancing yang memunculkan berbagai macam opini, tidak hanya opini yang positif tapi juga yang negatif [4]. Maka dari itu, Twitter di anggap lebih diminati oleh masyarakat indonesia dikarenakan twitter dirasa lebih mudah untuk mengungkapkan opininya [5].

Berdasarkan latar belakang yang dikemukakan di atas maka dapat dirumuskan masalah penelitian bahwa, Bagaimana implementasi algoritma Naive Bayes Classifier (NBC) dalam mengklasifikasikan data tweet pada media sosial twitter apakah data tweet tersebut termasuk ke dalam kelas bersentimen positif atau negatif? Tujuan dari penelitian ini, untuk menemukan dan mengkategorikan opini negatif atau positif, dari pembahasan physical distancing. Agar penerapan kebijakan Physical Distancing bisa sampai tepat informasinnya kepada masayarakat. Selain itu agar masalah yang sedang di tinjau lebih terarah dan tercapai sasaran yang telah ditentukan, maka harus diberikan batasan masalah yakni, tweet yang akan digunakan yaitu kalimat tweet yang berada di lingkup indonesia [6].

\section{Tinjauan Literatur}

Penelitian sebelumnya yang pernah dilakukan berkaitan dengan masalah yang dihadapi penulis yaitu dengan judul "Analisis Sentimen Masyarakat pada Media Sosial Twitter Terhadap Partai Politik Peserta Pemilu 2019 Menggunakan Naïve Bayes Classifier" penelitian dilakukan oleh Adiati et al. pada tahun 2019 Pada penelitian ini hasil pengujian dan analisis yang dilakukan oleh penulis dengan akurasi mencapai 78,03\% [7] .

Penelitian lainnya yaitu "Analisis Sentimen Opini Masyarakat Terhadap Acara Televisi pada Twitter dengan Retweet Analysis dan Nä̈ve Bayes Classifier" yang dilakukan oleh (Berlian et al. pada tahun 2019 dengan hasil pengujian dan analisis mencapai tingkat akurasi 61\% [8].

Penelitian selanjutnya yaitu "Sentiment Analysis of the Indonesian Police Mobile Brigade Corps Based on Twitter Posts Using the SVM and NB Methods" yang dilakukan oleh Pratama et al. tahun 2019 dengan tingkat akurasi 86,96\% [9] dan "Optimization Sentiments of Analysis from Tweets in myXLCare using Nä̈ve Bayes Algorithm and Synthetic Minority Over Sampling Technique Method" yang di lakukan oleh Saputra et al. pada tahun 2020 yang akurasinya mencapai 86,33\% [10]. Ada pula peneletian lain yaitu "Analisis Sentimen Tentang Opini Pilkada DKI 2017 Pada Dokumen Twitter Berbahasa Indonesia Menggunakan Nä̈ve Bayes dan Pembobotan Emoji” oleh Rossi et al. tahun 2017 dengan tingkat akurasi 68,52\% untuk kondisi pembobotan tekstual, 75,93\% untuk pembobotan non-tesktual, dan 74,81\% [11].

Selain itu ada penelitian lain pula yaitu "Implementasi Metode K-Means dan Nä̈ve Bayes Classifier untuk Analisis Sentimen Pemilihan Presiden (Pilpres) 2019" yang di lakukan oleh Kurniawan and Susanto di tahun 2019 dengan nilai akurasi rata-rata $93.35 \%$ dan error rate sebesar $6.66 \%[12]$.

Tujuan dari penelitian ini adalah untuk mengklasifikasikan tweet mengenai physical distancing di Twitter. Proses klasifikasi dilakukan dengan memisahkan tweet positif atau negatif melalui analisis sentimen. Algoritma yang akan di gunakan untuk pengklasifikasian dalam penelitian ini adalah Naive Bayes Classifier (NBC). Nä̈ve bayes merupakan salah satu metode data mining yang dapat digunakan dalam penelitian text mining khususnya analisis sentimen, seperti yag diungkap olehXhemali et al., pada tahun 2009 Salah satu teknik pembelajaran dari text mining untuk analisis sentimen adalah Naive Bayes Classifier. Metode Naive Bayes Classifier dianggap sebagai metode yang berpotensi baik untuk melakukan klasifikasi data daripada metode klasifikasi lainnya dalam hal akurasi dan komputasi [13].

Dari beberapa penelitian sebelumnya yang dijadikan sebagai referensi, algoritma Naive Bayes Classification yang dipakai untuk kasifikasi dalam penelitian text mining efektif untuk dipakai. Ratarata hasil penelitian menghasilkan nilai baik meski ada beberapa yang nilainya masih dibawah standar baik. Dalam penelitian ini, menghasilkan nilai akurasi yang baik dan penelitian selanjutnya bisa menggunakan fitur optimasi untuk lebih meningkatkan nilai akurasi lebih baik lagi.

\section{Metode Penelitian}

Metode penelitian yang dilakukan untuk menganalisis permasalahan diatas menggunakan teknik Data Mining dengan algoritma Naive Bayes seperti gambar dibawah ini : 


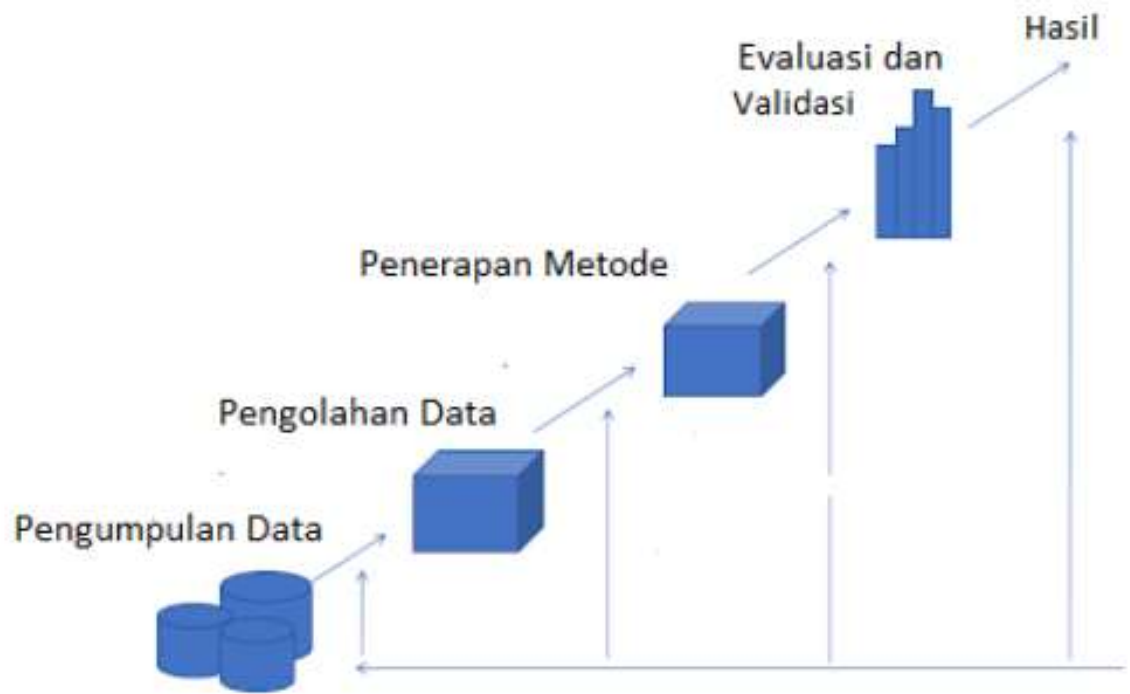

Gambar 1. Alur Diagram Penelitian

Tahapan penelitian yang dilakukan oleh penulis dalam melakukan penelitian ini seperti kegiatan di bawah ini :

\subsection{Pengambilan Data}

Dataset yang digunakan dalam penelitian ini adalah data mengenai kebijakan pemerintah mengenai physical distancing di dapat dari twitter dengan query "physical distancing" dengan metode crawling menggunakan RapidMiner.

\subsection{Pengolahan Data}

Tahap awal ini gunakan untuk mengolah data teks menjadi suatu analisa sentimen. Terdapat beberapa metode yang digunakan pada tahap ini diantaranya:

1. Tokenization

Tokenization dapat diartikan sebuah proses untuk memisahkan data teks menjadi beberapa token

2. Stopwords

Tahap ini berguna untuk membuang kata yang lebih dari 3 huruf dan termasuk dalam stopwrds.

3. Transform Case

Digunakan untuk mengubah karakter huruf kapital menjadi huruf kecil.

4. Filter Token (by length)

Digunakan untuk pemilihan token dengan ukuran panjang minimal 3 karakter (huruf) meski diantaranya adalah stopwords.

5. Weighting

Dilakukan berdasarkan jumlah kemunculan kata-kata dalam suatu dokumen, sehingga dokumen dapat direpresentasikan dalam vektor. Bobot fitur yang digunakan adalah Term Frequency-Inverse Frecuency Document (TF-IDF).

\subsection{Penerapan Metode}

Penerapan metode yang dilakukan menggunakan metode Naive Bayes Classification, pada tahap ini data dianalisis, lalu diterapkan model-model yang sesuai dengan jenis data. Model yang diusulkan dalam penelitian ini yaitu naive bayes.

\subsection{Evaluasi dan Validasi}

Validasi merupakan pembuktian dari suatu proses atau metode yang memberikan hasil yang konsisten. Evaluasi kinerja dilakukan untuk menguji hasil klasifikasi dengan mengukur nilai kinerja yang dilakukan oleh sistem. Parameter pengujian yang digunakan untuk mengevaluasi adalah akurasi atau kebenaran tingkat proses klasifikasi yang perhitungannya diperoleh dari table matriks. 
Metode Penelitian memberikan penjelasan tentang langkah-langkah, data, lokasi penelitian, metode evaluasi yang digunakan serta penjelasan terstruktur tentang algoritma atau metode dari penelitian yang dibahas.

\section{HASIL DAN PEMBAHASAN}

Perhitungan dilakukan dengan menerapkan langkah-langkah yang sudah dituliskan pada bab 3 , diantaranya :

\subsection{Pengambilan Data}

Data yang digunakan dalam penelitian ini merupakan opini berbahasa indonesia mengenai kebijakan Physical distancing yang dikeluarkan oleh pemerintah guna menekan penyebaran virus covid-19 yang sedang melanda beberapa negara di belahan dunia. Data diambil dari media sosial twitter dengan prses Crawling. Crawling data menggunakan aplikasi RapidMiner dengan query Physical distancing dan diambil sebanyak 1000 data tetapi setelah dilakukan filter dari cuitan tersebut dengan menghapus data yang double maka setelah di filter data yang terambil yaitu sebanyak 547 tweets.

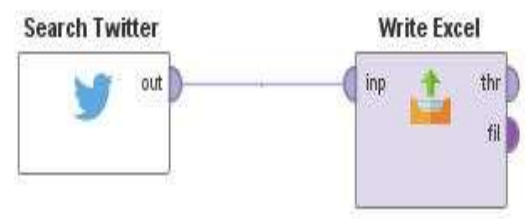

\section{Gambar 2. Proses Crawling}

Proses crawling dilakukan untuk mendapatkan data teks dari twitter secara manual dengan bahasa pemrograman perl.

\subsection{Pengolahan Data}

Pada tahapan ini dilakukan pengolahan data teks menjadi anaisis sentimen [14]. Berikut tahapan preprocessing yang dilakukan:

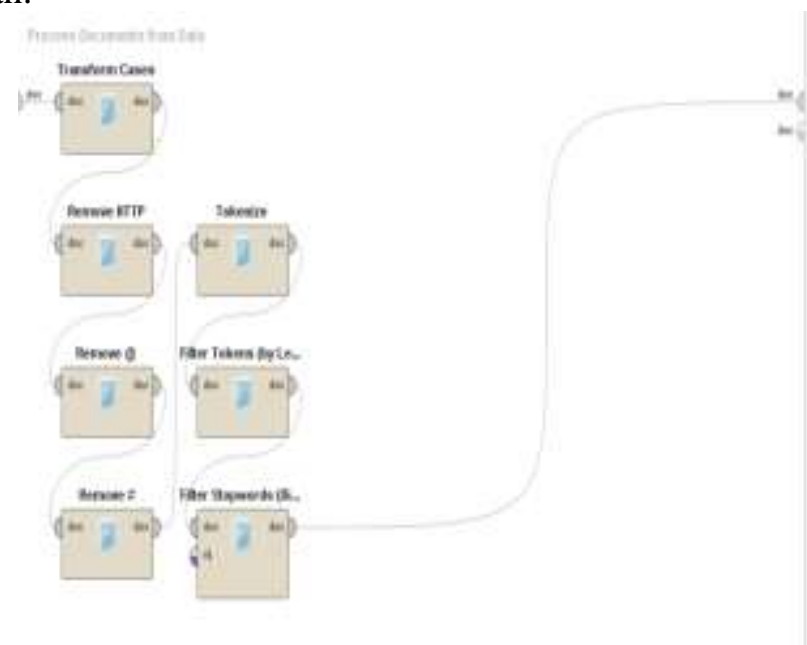

Gambar 3. Proses Preprocessing Pada Rapidminer

Pada tahapan ini, data yang sudah dikumpulkan, kemudian dilakukan proses cleansing dan hanya menyisakan kata-kata saja tanpa ada tanda baca dalam data.

1. Tokenization

Tahap tokenization dilakukan guna menghilangkan tanda baca, simbol dan karakter yang bukan berupa huruf pada setiap komentar 
Tabel 1. Hasil dari Tokenization

\begin{tabular}{|c|c|}
\hline $\begin{array}{l}\text { Teks sebelum dilakukan } \\
\text { proses }\end{array}$ & $\begin{array}{lll}\text { Teks setelah dilakukan } \\
\text { proses }\end{array}$ \\
\hline $\begin{array}{l}\text { masih belum paham apa } \\
\text { bedanya "social distancing" } \\
\text { dan "physical distancing"? }\end{array}$ & $\begin{array}{l}\text { masih belum paham apa } \\
\text { bedanya social distancing } \\
\text { dan physical distancing }\end{array}$ \\
\hline $\begin{array}{l}\text { masyarakat harus disiplin } \\
\text { dalam menerapkan jaga } \\
\text { jarak sosial (physical / } \\
\text { social distancing), dan } \\
\text { meniaga kehersihan tubuh }\end{array}$ & $\begin{array}{lr}\text { masyarakat harus } & \text { disiplin } \\
\text { dalam menerapkan jaga jarak } \\
\text { social physical social } \\
\text { distancing dan menjaga } \\
\text { kebersihan tubuh. }\end{array}$ \\
\hline
\end{tabular}

Dalam proses Tokenization, tanda baca yang terdapat dalam kalimat akan dihapus.

\section{Stopwords}

Pada tahap ini akan menyempurnakan tahap filter token. Kata-kata yang dibuang yaitu kata-kata yang tidak relevan atau tidak memiliki makna. Dalam proses stopwords, juga dilakukan proses stemming, yakni dengan mengubah kata hubung menjadi kata dasar dalam bahasa Indonesia.

\section{Transform Case}

Rapidminer akan mengubah kapitalisasi karakter (huruf) menjadi kecil untuk semua kata atau huruf pada tahap ini. Kemudian seluruh isi komentar akan menjadi non-kapital [15].

Tabel 2. Hasi dari Transform Case

\begin{tabular}{lrlr}
\hline $\begin{array}{l}\text { Teks sebelum dilakukan } \\
\text { proses }\end{array}$ & $\begin{array}{l}\text { Teks } \\
\text { proses }\end{array}$ \\
\hline Masih belum paham & masih belum paham \\
apa bedanya "social & apa bedanya "social & dilakukan \\
distancing" dan "physical & distancing" dan "physical \\
distancing"? & & distancing"? \\
& & \\
Masyarakat harus disiplin & masyarakat harus disiplin \\
dalam menerapkan jaga jarak & dalam menerapkan jaga jarak \\
sosial (physical / social & sosial (physical / social \\
distancing), dan menjaga & distancing), dan menjaga \\
kebersihan tubuh. & kebersihan tubuh. \\
\hline
\end{tabular}

4. Filter Token (by lenght)

Pada tahap ini dilakukan pemilihan token dengan ukuran panjang minimal 4 karakter (huruf). 


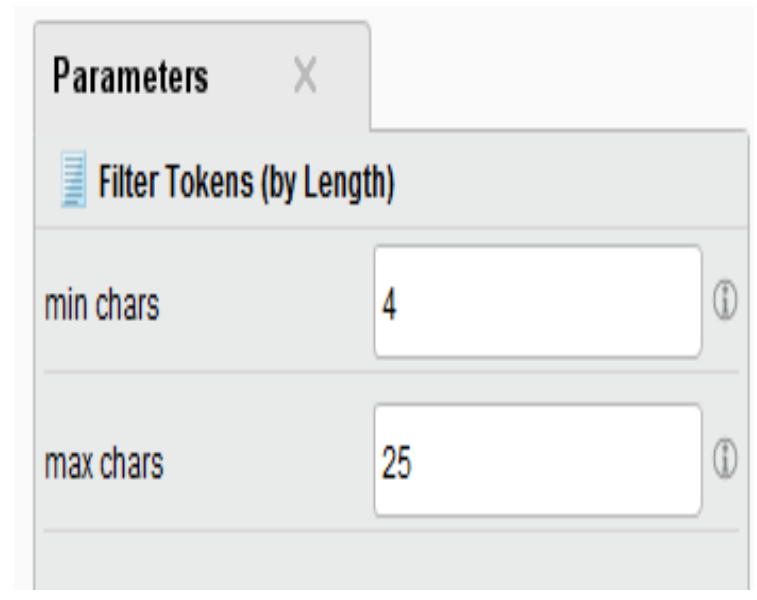

Gambar 4. Parameter dari Filter Token (by lenght)

Pada gambar diatas, dijelaskan bahwa jika kata yang kurang dari 4 huruf namun termasuk dalam stopwords akan tetap dibuang.

\subsection{Penerapan Metode}

Proses perhitungan untuk menentukan akurasi mengunakan Model Naive Bayes terdapat proses Training, Learning dan Testing. Proses ini merupakan proses dengan memberikan pola data terhadap mesin. Nantinya mesin akan mempelajari pola data tersebut sehingga hasilnya akan dijadikan sebagai rujukan pola baru yang akurat dalam pemodelan hasil. Dalam tahap ini urutan - urutan pengujian yang dilakukan sama hal nya dengan pengujian model lainnya pada Rapid Miner.

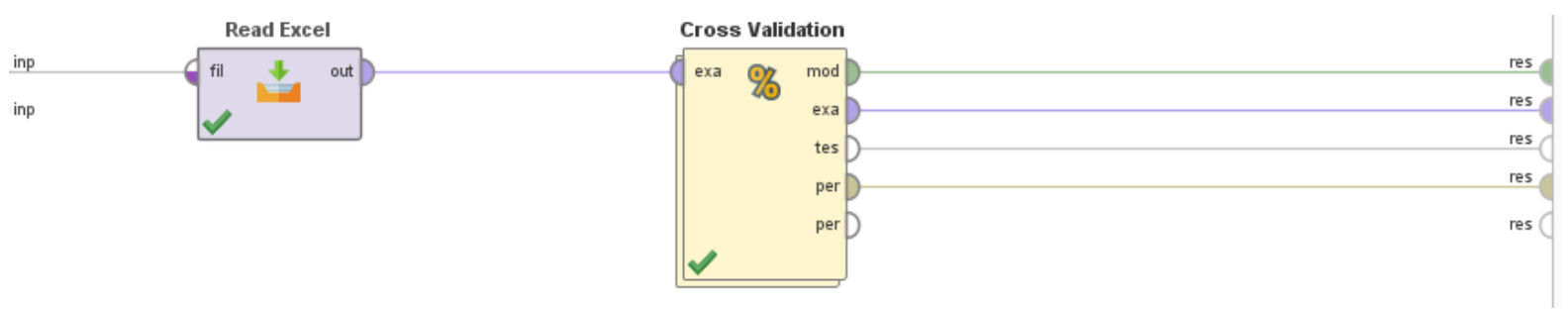

\section{Gambar 5. Operator Cross Validation K-Fold}

Pada tahapan ini, mengatur proses validasi dengan number of folds 10 .

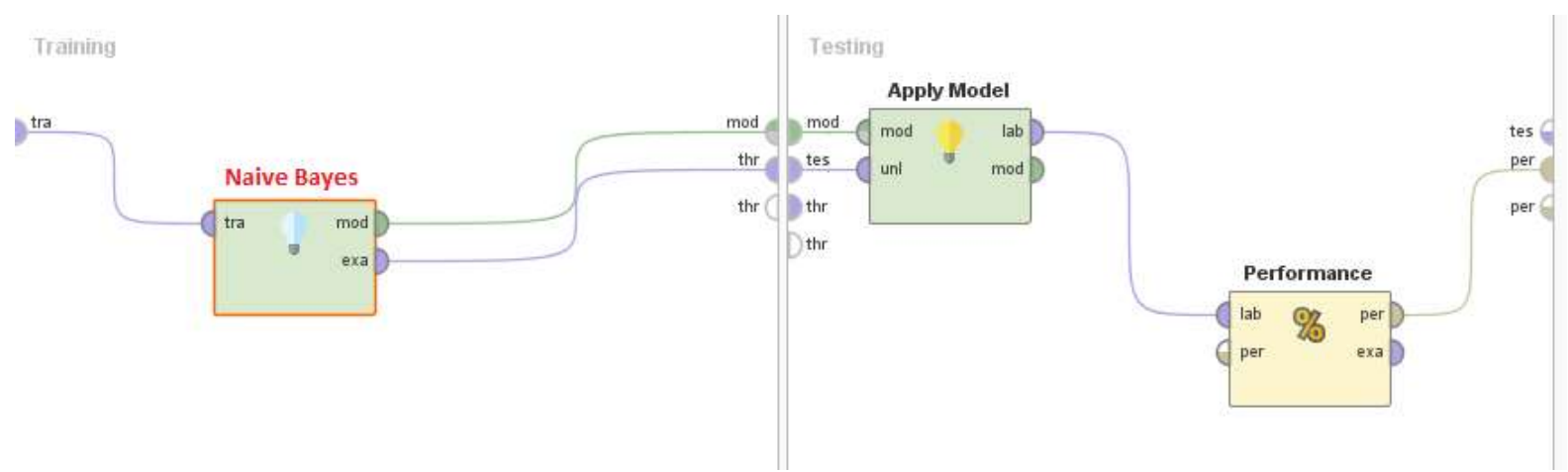

\section{Gambar 6. Proses Insert Training}

Proses selanjutnya yaitu insert model yang akan di training, dalam hal ini memasukkan algoritma yang dipilih yakni Naive Bayes dengan menggunakan dataset dengan cycles 200, learning rate 0,01 dan momentum 0,9 . 


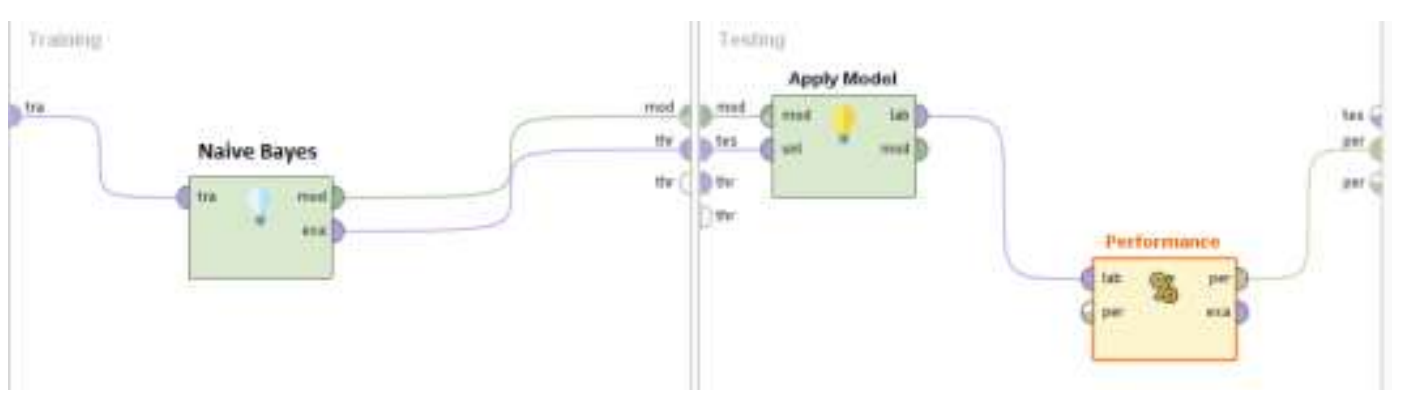

Gambar 7. Proses Insert Apply dan Performance

Proses terakhir yaitu proses testing, dimana memasukkan apply model, performance dan AUC. Pada proses ini, data dibagi menjadi data training sebesar $80 \%$ dan data tes sebesar $20 \%$.

\subsection{Validasi dan Evaluasi}

Pada tahap ini proses evaluasi menggunakan metode confusion matrix. Model confusion matrix akan membentuk matriks yang terdiri dari accuracy, true positif dan true negatif, recall serta precision. Berikut merupakan hasil dari confusion matrix pada algoritma naïve bayes classifier.

\begin{tabular}{|c|c|c|c|}
\hline & thaProbe & tyaliagest & tessoncosin \\
\hline todpd Puste & 14 & 11 & wesh \\
\hline prad liagale & 181 & 131 & $466 \%$ \\
\hline cassisal & $423 \%$ & 51795 & \\
\hline
\end{tabular}

\section{Gambar 8. Accuracy Analyst}

Hasil accuracy pengujian naïve bayes untuk analisis sentimen pada media sosial instagram memperoleh hasil sebesar 50,26\%.

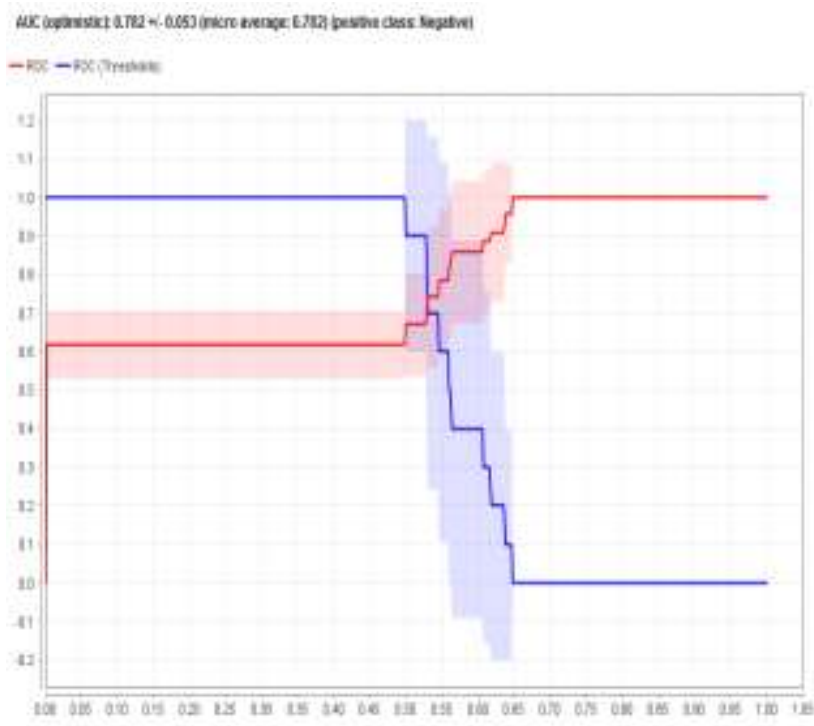

\section{Gambar 9. Nilai ROC Curve}

Hasil dari Uji AUC sebesar 0.782 dan garis yang dibentuk semakin melebar dan tidak mengerucut. Hal tersebut menunjukkan hasil akurasi yang diperoleh masuk dalam kategori baik. 


\section{Kesimpulan}

Berdasarkan hasil analisa yang dilakukan terkait sentimen terhadap kebijakan physical distancing dengan menggunakan metode nä̈ve bayes dapat diambil beberapa kesimpulan bahwa Metode naïve bayes merupakan metode yang cukup baik dalam pengklasfikasian data mining ataupun text mining. hal ini dikarenakan algoritma tersebut dapat menghasilkan nilai akurasi yang cukup tinggi yakni diatas lima puluh persen.

\section{Referensi}

[1] A. Rossi, T. Lestari, R. Setya Perdana, and M. A. Fauzi, "Analisis Sentimen Tentang Opini Pilkada Dki 2017 pada Dokumen Twitter Berbahasa Indonesia Menggunakan Näive Bayes dan Pembobotan Emoji,” J. Pengemb. Teknol. Inf. Dan Ilmu Komput., Vol. 1, No. 12, pp. 17181724, 2017, [Online]. Available: http://J-Ptiik.Ub.Ac.Id.

[2] I. Indriati, M. Marji, and S. Pakpahan, "Analisis Sentimen Tentang Opini Performa Klub Sepak Bola pada Dokumen Twitter Menggunakan Support Vector Machine, dengan perbaikan Kata Tidak Baku," J. Pengemb. Teknol. Inf. dan Ilmu Komput., 2019.

[3] I. Hanafi and R. Ferdiansyah, "Sentimen Analisis Twitter Pada Hastag PSBB Di Indonesia dalam Menghadapi Pandemi Covid-19," Vol. 1, No. 3, pp. 1011-1022, 2020.

[4] B. U. Manalu, "Analisis Sentimen Pada Twitter Menggunakan Text Mining Skripsi Boy Utomo Manalu," Teknol. Inf. Fak. Ilk. Unsut, 2014.

[5] A. Syakuro, "Pada Media Sosial Menggunakan Metode Naïve Bayes Classifier ( NBC) Dengan Seleksi Fitur Information Gain ( IG ) Halaman Judul Skripsi Oleh: Abdan Syakuro," Anal. Sentimen Masy. Terhadap E-Commerce Pada Media Sos. Menggunakan Metod. Naive Bayes Classif. Dengan Sel. Fitur Inf. Gain, 2017.

[6] A. V. Sudiantoro and E. Zuliarso, "Analisis Sentimen Twitter Menggunakan Text Mining dengan Algoritma Naïve Bayes Classifier," Pros. Sintak 2018, pp. 398-401, 2018.

[7] A. R. Adiati, A. Herdiani, W. Astuti, and M. Kom, "Analisis Sentimen Masyarakat pada Media Sosial Twitter terhadap Partai Politik Peserta Pemilu 2019 Menggunakan Naive Bayes Classifier," Vol. 6, No. 2, 2019.

[8] T. F. Berlian, A. Herdiani, W. Astuti, and M. Kom, "Analisis Sentimen Opini Masyarakat terhadap Acara Televisi pada Twitter dengan Retweet Analysis dan Naive Bayes Classifier," Vol. 6, No. 2, pp. 8660-8669, 2019.

[9] B. Pratama, D. D. Saputra, D. Novianti, and E. P. Purnamasari, "Sentiment Analysis Of The Indonesian Police Mobile Brigade Corps Based on Twitter Posts using he SVM and NB Methods Sentiment Analysis Of the Indonesian Police Mobile Brigade Corps Based On Twitter Posts Using The SVM and Nb Methods," 2019, doi: 10.1088/17426596/1201/1/012038.

[10] D. D. Saputra, W. Gata, N. K. Wardhani, and K. Sakho, "Optimization Sentiments Of Analysis From Tweets In Myxlcare Using Naïve Bayes Algorithm and Synthetic Minority Over Sampling Technique Method Optimization Sentiments of Analysis From Tweets In Myxlcare Using Naïve Bayes Algorithm and Synthetic Minority Ov," 2020, doi: 10.1088/17426596/1471/1/012014.

[11] Y. S. Mahardhika and E. Zuliarso, "Analisis Sentimen Terhadap Pemerintahan Joko Widodo Pada Media Sosial Twitter Menggunakan Algoritma Naives Bayes," Pros. Sintak 2018, 2018.

[12] I. Kurniawan and A. Susanto, "Implementasi Metode K-Means dan Naïve Bayes Classifier Untuk Analisis Sentimen Pemilihan Presiden (Pilpres) 2019," Eksplora Inform., Vol. 9, No. 1, pp. 1-10, 2019, doi: 10.30864/Eksplora.V9i1.237.

[13] D. Xhemali, C. J. Hinde, and R. G. Stone, "Naïve Bayes vs Decision Trees vs Neural Networks in The Classification of Training Web Pages," Vol. 4, No. 1, pp. 16-23, 2009.

[14] T. G. Laksana and P. Rizkiyah, "Analisa Sentimen Menggunakan Naïve Bayes untuk Mengetahui Presentase Komentar pada Aplikasi Go-Jek," 2018.

[15] E. Junianto and D. Riana, "Penerapan Pso Untuk Seleksi Fitur Pada Klasifikasi Dokumen Berita Menggunakan NBC," Vol. 4, No. 1. pp. 38-45, 2017. 